\section{Air pollution and lung cancer incidence in 17 European cohorts: prospective analyses from the European Study of Cohorts for Air Pollution Effects (ESCAPE)}

\begin{abstract}
Ole Raaschou-Nielsen, Zorana J Andersen, Rob Beelen, Evangelia Samoli, Massimo Stafoggia, Gudrun Weinmayr, Barbara Hoffmann, Paul Fischer, Mark Jieuwenhuijsen, Bert Brunekreef, Wei W Xun, Klea Katsouyanni, Konstantina Dimakopoulou, Johan Sommar, Bertil Forsberg, Lars Modig, Anna Oudin, Bente Oftedal, Per E Schwarze, Per Nafstad, Ulf De Faire, Nancy L Pedersen, Claes-Göran Östenson, Laura Fratiglioni, Johanna Penell, Michal Korek, Göran Pershagen, Kirsten T Eriksen, Mette Sørensen, Anne Tjønneland, Thomas Ellermann, Marloes Eeftens, Petra H Peeters, Kees Meliefste, Meng Wang, Bas Bueno-de-Mesquita, TimothyJ Key, Kees de Hoogh, Hans Concin, Gabriele Nagel, Alice Vilier, Sara Grioni, Vittorio Krogh, Ming-Yi Tsai, Fulvio Ricceri, Carlotta Sacerdote, Claudia Galassi, Enrica Migliore, Andrea Ranzi, Giulia Cesaroni, Chiara Badaloni, Francesco Forastiere, Ibon Tamayo, Pilar Amiano, Miren Dorronsoro, Antonia Trichopoulou, Christina Bamia, Paolo Vineis*, Gerard Hoek*
\end{abstract}

\section{Summary}

Background Ambient air pollution is suspected to cause lung cancer. We aimed to assess the association between long-term exposure to ambient air pollution and lung cancer incidence in European populations.

Methods This prospective analysis of data obtained by the European Study of Cohorts for Air Pollution Effects used data from 17 cohort studies based in nine European countries. Baseline addresses were geocoded and we assessed air pollution by land-use regression models for particulate matter (PM) with diameter of less than $10 \mu \mathrm{m}\left(\mathrm{PM}_{10}\right)$, less than $2.5 \mu \mathrm{m}\left(\mathrm{PM}_{2.5}\right)$, and between 2.5 and $10 \mu \mathrm{m}\left(\mathrm{PM}_{\text {coarse }}\right)$, soot $\left(\mathrm{PM}_{2.5 \mathrm{sabs} r b a n c e}\right)$, nitrogen oxides, and two traffic indicators. We used Cox regression models with adjustment for potential confounders for cohort-specific analyses and random effects models for meta-analyses.

Findings The 312944 cohort members contributed 4013131 person-years at risk. During follow-up (mean 12.8 years), 2095 incident lung cancer cases were diagnosed. The meta-analyses showed a statistically significant association between risk for lung cancer and $\mathrm{PM}_{10}$ (hazard ratio [HR] 1.22 [95\% CI 1.03-1.45] per $10 \mu \mathrm{g} / \mathrm{m}^{3}$ ). For $\mathrm{PM}_{2.5}$ the HR was 1.18 $(0 \cdot 96-1 \cdot 46)$ per $5 \mu \mathrm{g} / \mathrm{m}^{3}$. The same increments of $\mathrm{PM}_{10}$ and $\mathrm{PM}_{2.5}$ were associated with HRs for adenocarcinomas of the lung of $1.51(1.10-2 \cdot 08)$ and $1.55(1.05-2 \cdot 29)$, respectively. An increase in road traffic of 4000 vehicle-km per day within $100 \mathrm{~m}$ of the residence was associated with an HR for lung cancer of $1.09(0 \cdot 99-1 \cdot 21)$. The results showed no association between lung cancer and nitrogen oxides concentration (HR 1.01 [0.95-1.07] per $20 \mu \mathrm{g} / \mathrm{m}^{3}$ ) or traffic intensity on the nearest street (HR 1.00 [0.97-1.04] per 5000 vehicles per day).

Interpretation Particulate matter air pollution contributes to lung cancer incidence in Europe.

Funding European Community's Seventh Framework Programme.

\section{Introduction}

Lung cancer is one of the most common cancers and has a poor prognosis. Active smoking is the main cause, but occupational exposures, residential radon, and environmental tobacco smoke are also established risk factors. Furthermore, lower socioeconomic position has been associated with a higher risk for lung cancer. ${ }^{1}$ Ambient air pollution, specifically particulate matter with absorbed polycyclic aromatic hydrocarbons and other genotoxic chemicals, is suspected to increase the risk for lung cancer. Results of several epidemiological studies have shown higher risks for lung cancer in association with various measures of air pollution ${ }^{2-11}$ and suggested an association mainly in non-smokers ${ }^{4,12}$ and never-smokers ${ }^{1,14}$ and in individuals with low fruit consumption. ${ }^{413}$ In developed countries, overall lung cancer incidence rates have stabilised during the past few decades, but major shifts have been recorded in the frequencies of different histological types of lung cancer, with substantial relative increases in adenocarcinomas and decreases in squamouscell carcinomas. ${ }^{15}$ Changes in tobacco blends ${ }^{15}$ and ambient air pollution ${ }^{1,17}$ might have contributed to these shifts.

Within the European Study of Cohorts for Air Pollution Effects (ESCAPE), we aimed to analyse data from 17 European cohort studies with a wide range of exposure levels to investigate the following hypotheses: that ambient air pollution at the residence (specifically particulate matter) is associated with risk for lung cancer; that the association between air pollution and risk for lung cancer is stronger for non-smokers and people with low fruit intake; and that the association with air pollution is stronger for adenocarcinomas and squamous-cell carcinomas than for all lung cancers combined.

\section{Methods}

Study design and participants

This study is a prospective analysis of data obtained by ESCAPE-an investigation into the long-term effects of

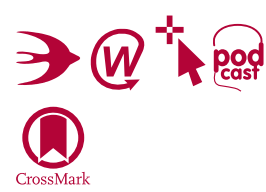

\section{(1)}


Prof B Hoffmann MD); Medical Faculty, Heinrich Heine University of Düsseldorf, Düsseldorf, Germany (Prof B Hoffmann); National Institute for Public Health and the Environment, Bilthoven, Netherlands (P Fischer MSc, B Bueno-de-Mesquita PhD); Center for Research in Environmental Epidemiology, Parc de Recerca Biomèdica de

Barcelona, Barcelona, Spain (M) Nieuwenhuijsen PhD); Julius Center for Health Sciences and Primary Care, University Medical Center Utrecht, Utrecht, Netherlands (Prof B Brunekreef, Prof P H Peeters PhD); MRC-HPA Centre for Environment and Health, Department of Epidemiology and Biostatistics, Imperial College London, St Mary's Campus,

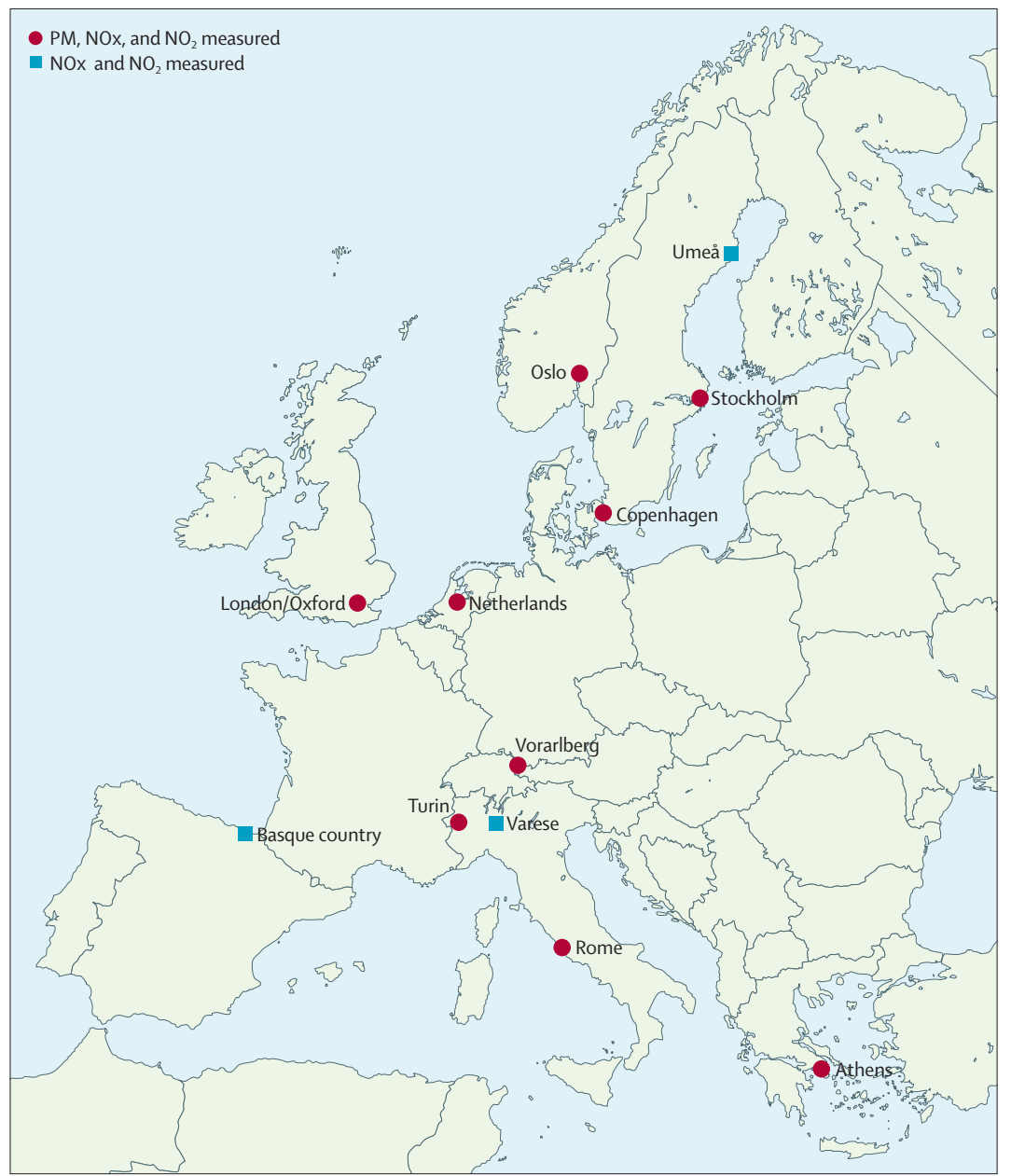

Figure 1: Areas where cohort members lived, measurements were taken, and land-use regression models for prediction of air pollution were developed

$\mathrm{NO}_{2}=$ nitrogen dioxide. $\mathrm{NOx}=$ nitrogen oxides (the sum of nitric oxide and nitrogen dioxide). $\mathrm{PM}=$ particulate matter.
Prevention Programme [VHM\&PP]), Italy (EPIC-Varese, EPIC-Turin, Italian Studies of Respiratory Disorders in Childhood and Environment [SIDRIA]-Turin, SIDRIA-Rome), Spain (EPIC-San Sebastian), and Greece (EPIC-Athens; figure 1). The study areas were mostly large cities and the surrounding suburban or rural communities. Some of the cohorts covered large regions of the country, such as EPIC-MORGEN in the Netherlands, EPIC-Oxford in the UK, and the VHM\&PP cohort in Austria. For DCH, EPIC-Oxford, VHM\&PP, and EPIC-Athens, exposure to air pollution was assessed for part of the original cohort only, and only those parts were analysed (restrictions are specified in the appendix pp 8,11,12, and 18). The use of cohort data in ESCAPE was approved by the local ethical and data protection authorities. Each cohort study followed the rules for ethics and data protection set up in the country in which they were based.

\section{Procedures}

The association between long-term exposure to air pollution and incidence of lung cancer was analysed in each cohort separately at the local centre by common standardised protocols for exposure assessment outcome definition, confounder models, and statistical analyses. Cohort-specific effect estimates were combined by meta-analysis at the Danish Cancer Society Research Center, Copenhagen, Denmark. A pooled analysis of all cohort data was not possible due to data transfer and privacy issues.

The main outcome was all cancers of the lung; secondary analyses addressed adenocarcinomas and squamous-cell carcinomas of the lung. We included cancers located in the bronchus and the lung (International Statistical Classification of Diseases and Related Health Problems, 10th revision [ICD10] and International Classification of Diseases for Oncology, 3rd edition [ICDO3] C34-0-C34 -9). We only included primary cancers (ie, not metastases). Each cancer was histologically characterised, and data for squamous-cell carcinomas (ICDO3 8050-8084; fifth digit morphology code 3) and adenocarcinomas (ICDO3 8140-8384; fifth digit morphology code 3) in particular were obtained. Lymphomas in the lung (ICDO3 morphology codes 9590/3-9729/3) were not included. The characterisation of histology was based on routine pathology; this study did not include verification of tumour histology. The cohort members were followed up for cancer incidence in national or local cancer registries, except for EPIC-Athens, in which cancer cases were identified by questionnaires and telephone interviews followed by verification of medical records, and the SIDRIA cohorts, for which hospital discharge and mortality register data were used.

\section{Exposure assessment}

Air pollution concentrations at the baseline residential addresses of study participants were estimated by land-use regression models in a three-step, standardised 
procedure. First, particulate matter with an aerodynamic diameter of less than $10 \mu \mathrm{m}\left(\mathrm{PM}_{10}\right)$, particulate matter with aerodynamic diameter of less than $2.5 \mu \mathrm{m}\left(\mathrm{PM}_{2.5}\right)$, blackness of the $\mathrm{PM}_{2.5}$ exposed filter $\left(\mathrm{PM}_{2.5 a b s o r b a n c e}\right)$, determined by measurement of light reflectance (a marker for soot and black carbon), nitrogen oxides (NOx), and nitrogen dioxide $\left(\mathrm{NO}_{2}\right)$ were measured during different seasons at locations for each cohort population between October, 2008, and April, 2011. ${ }^{18,19} \mathrm{PM}_{\text {coarse }}$ was calculated as the difference between $\mathrm{PM}_{10}$ and $\mathrm{PM}_{2.5}$ (ie, PM with diameter 2.5-10 $\mu \mathrm{m}$ ). In three areas, only $\mathrm{NO}_{2}$ and NOx were measured (figure 1). Second, land-use regression models were developed for each pollutant in London, UK (WW Xun MPH, each study area, with the yearly mean concentration as the dependent variable and an extensive list of geographical attributes as possible predictors. ${ }^{20,21}$ Generally, predictors for $\mathrm{PM}_{10}, \mathrm{PM}_{2.5}, \mathrm{NOx}$, and $\mathrm{NO}_{2}$ were related to traffic or roads and population or building density. Variables related to industry, proximity to a port, and altitude were also predictors in some models. The models generally explained a large fraction of measured spatial variation, the $R^{2}$ from leave-one-out cross-validation usually falling between 0.60 and 0.80 (appendix p 20). Finally, the models were used to assess
$\mathrm{K}$ de Hoogh $\mathrm{PhD}$

Prof P Vineis MPH); Division of Occupational and Environmental Medicine, Department of Public Health and Clinical Medicine, Umeå University, Umeå, Sweden (J Sommar MSc, Prof B Forsberg PhD, L Modig PhD, A Oudin PhD); Norwegian Institute of Public Health, Oslo, Norway (B Oftedal PhD,

\begin{tabular}{|c|c|c|c|c|c|c|c|c|c|c|c|c|c|}
\hline & $\begin{array}{l}\text { Total } \\
\text { participants }\end{array}$ & $\begin{array}{l}\text { Age at } \\
\text { baseline } \\
\text { (years) }\end{array}$ & $\begin{array}{l}\text { All lung } \\
\text { cancer }\end{array}$ & $\begin{array}{l}\text { Adeno- } \\
\text { carcinoma* }\end{array}$ & $\begin{array}{l}\text { Squamous- } \\
\text { cell } \\
\text { carcinoma* }\end{array}$ & $\begin{array}{l}\mathrm{PM}_{10} \\
\left(\mu \mathrm{g} / \mathrm{m}^{3}\right)\end{array}$ & $\begin{array}{l}\mathrm{PM}_{\text {coarse }} \\
\left(\mu \mathrm{g} / \mathrm{m}^{3}\right)\end{array}$ & $\begin{array}{l}\mathrm{PM}_{2.5} \\
\left(\mu \mathrm{g} / \mathrm{m}^{3}\right)\end{array}$ & $\begin{array}{l}\mathrm{PM}_{2-\text { sabsortance }} \\
\left(10^{-5} / \mathrm{m}\right)\end{array}$ & $\begin{array}{l}\mathrm{NO}_{2} \\
\left(\mu \mathrm{g} / \mathrm{m}^{3}\right)\end{array}$ & $\begin{array}{l}\text { NOx } \\
\left(\mu \mathrm{g} / \mathrm{m}^{3}\right)\end{array}$ & $\begin{array}{l}\text { Traffic on } \\
\text { nearest } \\
\text { street } \\
\text { (vehicles per } \\
\text { day) }\end{array}$ & $\begin{array}{l}\text { Traffic load on } \\
\text { major streets } \\
\text { within } 100 \mathrm{~m} \\
\text { (vehicle-km } \\
\text { per day) }\end{array}$ \\
\hline $\begin{array}{l}\text { EPIC-Umeå, } \\
\text { Sweden }\end{array}$ & 22136 & $\begin{array}{l}46 \cdot 0 \\
(12 \cdot 2)\end{array}$ & $\begin{array}{l}69 \\
(0 \cdot 31 \%)\end{array}$ & $34(0 \cdot 15 \%)$ & $18(0.08 \%)$ & NA & NA & NA & NA & $5 \cdot 2(2 \cdot 5)$ & $\begin{array}{r}8 \cdot 7 \\
(5 \cdot 7)\end{array}$ & 845 (1530) & $102(417)$ \\
\hline $\begin{array}{l}\text { HUBRO, Oslo, } \\
\text { Norway }\end{array}$ & 17640 & $\begin{array}{l}47 \cdot 8 \\
(15 \cdot 0)\end{array}$ & $\begin{array}{l}75 \\
(0.43 \%)\end{array}$ & $25(0 \cdot 14 \%)$ &.. & $\begin{array}{l}13 \cdot 5 \\
(3 \cdot 1)\end{array}$ & $\begin{array}{r}4 \cdot 0 \\
(2 \cdot 0)\end{array}$ & $\begin{array}{r}8 \cdot 9 \\
(1 \cdot 3)\end{array}$ & $1 \cdot 2(0 \cdot 3)$ & $20 \cdot 9(8 \cdot 0)$ & $\begin{array}{l}38 \cdot 3 \\
(15 \cdot 5)\end{array}$ & $2502(5117)$ & $821(1840)$ \\
\hline $\begin{array}{l}\text { SNAC-K, } \\
\text { Stockholm, } \\
\text { Sweden }\end{array}$ & 2384 & $\begin{array}{l}73 \cdot 1 \\
(10 \cdot 7)\end{array}$ & $\begin{array}{l}18 \\
(0.76 \%)\end{array}$ & $13+(0 \cdot 55 \%)$ &.. & $\begin{array}{l}16 \cdot 4 \\
(6 \cdot 0)\end{array}$ & $\begin{array}{r}8.6 \\
(4.8)\end{array}$ & $\begin{array}{r}8 \cdot 0 \\
(1 \cdot 3)\end{array}$ & $0.8(0.2)$ & $17 \cdot 5(4 \cdot 9)$ & $\begin{array}{l}33 \cdot 5 \\
(12 \cdot 6)\end{array}$ & 3888 (9886) & 2298 (3699) \\
\hline $\begin{array}{l}\text { SALT, Stockholm, } \\
\text { Sweden }\end{array}$ & 4732 & $\begin{array}{l}57 \cdot 9 \\
(10 \cdot 2)\end{array}$ & $\begin{array}{l}29 \\
(0 \cdot 61 \%)\end{array}$ & $12(0 \cdot 25 \%)$ &.. & $\begin{array}{l}14 \cdot 9 \\
(3 \cdot 9)\end{array}$ & $\begin{array}{r}7 \cdot 3 \\
(3 \cdot 0)\end{array}$ & $\begin{array}{l}7 \cdot 3 \\
(1 \cdot 3)\end{array}$ & $0.6(0.2)$ & $10 \cdot 9(4 \cdot 2)$ & $\begin{array}{l}18 \cdot 9 \\
(9 \cdot 4)\end{array}$ & $1460(3351)$ & $587(1623)$ \\
\hline $\begin{array}{l}\text { Sixty, Stockholm, } \\
\text { Sweden }\end{array}$ & 3813 & $\begin{array}{l}60 \cdot 4 \\
(0 \cdot 1)\end{array}$ & $\begin{array}{l}38 \\
(1.00 \%)\end{array}$ & $22(0.58 \%)$ & $5(0.13 \%)$ & $\begin{array}{l}15 \cdot 0 \\
(3 \cdot 8)\end{array}$ & $\begin{array}{r}7 \cdot 3 \\
(2 \cdot 9)\end{array}$ & $\begin{array}{c}7 \cdot 3 \\
(1 \cdot 3)\end{array}$ & $0.6(0.2)$ & $10 \cdot 7(4 \cdot 2)$ & $\begin{array}{l}18.6 \\
(9.4)\end{array}$ & $1453(3466)$ & $512(1446)$ \\
\hline $\begin{array}{l}\text { SDPP, Stockholm, } \\
\text { Sweden }\end{array}$ & 7116 & $\begin{array}{l}47 \cdot 1 \\
(5 \cdot 0)\end{array}$ & $\begin{array}{l}35 \\
(0.49 \%)\end{array}$ & $22(0 \cdot 31 \%)$ & $5(0.07)$ & $\begin{array}{l}13 \cdot 6 \\
(3 \cdot 2)\end{array}$ & $\begin{array}{r}6 \cdot 3 \\
(2 \cdot 4)\end{array}$ & $\begin{array}{r}6 \cdot 6 \\
(1 \cdot 2)\end{array}$ & $0.5(0.1)$ & $8 \cdot 4(1 \cdot 7)$ & $\begin{array}{l}14 \cdot 4 \\
(3 \cdot 3)\end{array}$ & $861(1621)$ & $110(423)$ \\
\hline $\begin{array}{l}\text { DCH, } \\
\text { Copenhagen, } \\
\text { Denmark }\end{array}$ & 37447 & $\begin{array}{l}56 \cdot 8 \\
(4 \cdot 4)\end{array}$ & $\begin{array}{l}638 \\
(1 \cdot 70 \%)\end{array}$ & $236(0.63 \%)$ & $106(0 \cdot 28 \%)$ & $\begin{array}{l}17 \cdot 1 \\
(1 \cdot 9)\end{array}$ & $\begin{array}{l}5 \cdot 7 \\
(1 \cdot 0)\end{array}$ & $\begin{array}{l}11 \cdot 3 \\
(0.9)\end{array}$ & $1.2(0.2)$ & $16 \cdot 3(7 \cdot 0)$ & $\begin{array}{l}26 \cdot 7 \\
(18 \cdot 4)\end{array}$ & 2991 (7209) & $1221(2332)$ \\
\hline $\begin{array}{l}\text { EPIC-MORGEN, } \\
\text { Netherlands }\end{array}$ & 15993 & $\begin{array}{l}43 \cdot 7 \\
(10 \cdot 7)\end{array}$ & $\begin{array}{l}92 \\
(0.58 \%)\end{array}$ & $32(0 \cdot 20 \%)$ & $24(0 \cdot 15 \%)$ & $\begin{array}{l}25 \cdot 6 \\
(1 \cdot 7)\end{array}$ & $\begin{array}{r}8.6 \\
(1 \cdot 1)\end{array}$ & $\begin{array}{l}16 \cdot 9 \\
(0.6)\end{array}$ & $1 \cdot 4(0 \cdot 2)$ & $23.8(7 \cdot 0)$ & $\begin{array}{l}36 \cdot 5 \\
(11 \cdot 8)\end{array}$ & $1535(4084)$ & 917 (1979) \\
\hline $\begin{array}{l}\text { EPIC-PROSPECT, } \\
\text { Netherlands }\end{array}$ & 14630 & $\begin{array}{l}57 \cdot 6 \\
(6 \cdot 0)\end{array}$ & $\begin{array}{l}112 \\
(0 \cdot 77 \%)\end{array}$ & $43(0 \cdot 29 \%)$ & $16(0.11 \%)$ & $\begin{array}{l}25 \cdot 3 \\
(1 \cdot 2)\end{array}$ & $\begin{array}{r}8.5 \\
(0.7)\end{array}$ & $\begin{array}{l}16 \cdot 8 \\
(0 \cdot 5)\end{array}$ & $1.4(0.2)$ & $26 \cdot 7(4 \cdot 6)$ & $\begin{array}{l}39 \cdot 6 \\
(10 \cdot 5)\end{array}$ & $1020(3433)$ & $678(1513)$ \\
\hline EPIC-Oxford, UK & 36832 & $\begin{array}{l}45 \cdot 3 \\
(13 \cdot 6)\end{array}$ & $\begin{array}{l}78 \\
(0 \cdot 21 \%)\end{array}$ & $19(0.05 \%)$ & $9(0.02 \%)$ & $\begin{array}{l}16 \cdot 1 \\
(2 \cdot 0)\end{array}$ & $\begin{array}{r}6.4 \\
(0.9)\end{array}$ & $\begin{array}{r}9 \cdot 8 \\
(1 \cdot 1)\end{array}$ & $1 \cdot 1(0 \cdot 3)$ & $24 \cdot 5(8 \cdot 0)$ & $\begin{array}{l}40 \cdot 9 \\
(15 \cdot 6)\end{array}$ & $1381(4345)$ & $373(1287)$ \\
\hline $\begin{array}{l}\text { VHM\&PP, } \\
\text { Vorarlberg, Austria }\end{array}$ & 108018 & $\begin{array}{l}42 \cdot 8 \\
(14 \cdot 9)\end{array}$ & $\begin{array}{l}678 \\
(0.63 \%)\end{array}$ & $223(0 \cdot 21 \%)$ & $157(0 \cdot 15 \%)$ & $\begin{array}{l}20 \cdot 7 \\
(2 \cdot 4)\end{array}$ & $\begin{array}{c}6.7 \\
(0.9)\end{array}$ & $\begin{array}{l}13 \cdot 6 \\
(1 \cdot 2)\end{array}$ & $1.7(0.2)$ & $19 \cdot 9(5 \cdot 5)$ & $\begin{array}{l}40 \cdot 0 \\
(9 \cdot 5)\end{array}$ & $1687(3582)$ & 294 (991) \\
\hline EPIC-Varese, Italy & 9506 & $\begin{array}{l}51 \cdot 6 \\
(8 \cdot 2)\end{array}$ & $\begin{array}{l}43 \\
(0.45 \%)\end{array}$ & $17(0 \cdot 18 \%)$ & $12(0 \cdot 13 \%)$ & NA & NA & NA & NA & $43 \cdot 8(17 \cdot 3)$ & $\begin{array}{l}86 \cdot 8 \\
(41 \cdot 9)\end{array}$ & NA & NA \\
\hline EPIC-Turin, Italy & 7216 & $\begin{array}{l}50 \cdot 4 \\
(7 \cdot 6)\end{array}$ & $\begin{array}{l}48 \\
(0.67 \%)\end{array}$ & $23(0 \cdot 32 \%)$ &.. & $\begin{array}{l}46 \cdot 6 \\
(4 \cdot 6)\end{array}$ & $\begin{array}{l}16 \cdot 6 \\
(3 \cdot 0)\end{array}$ & $\begin{array}{l}30 \cdot 1 \\
(2 \cdot 0)\end{array}$ & $3 \cdot 1(0.4)$ & $53 \cdot 0(10 \cdot 9)$ & $\begin{array}{l}96 \cdot 2 \\
(21 \cdot 5)\end{array}$ & 3903 (9164) & $465(912)$ \\
\hline SIDRIA-Turin, Italy & 4816 & $\begin{array}{l}44 \cdot 0 \\
(6 \cdot 2)\end{array}$ & $\begin{array}{l}19 \\
(0 \cdot 39 \%)\end{array}$ & .. &.. & $\begin{array}{l}48 \cdot 1 \\
(4 \cdot 1)\end{array}$ & $\begin{array}{l}17 \cdot 0 \\
(2 \cdot 5)\end{array}$ & $\begin{array}{l}31 \cdot 0 \\
(1 \cdot 7)\end{array}$ & $3.2(0.4)$ & $59 \cdot 8(10 \cdot 6)$ & $\begin{array}{l}107 \cdot 3 \\
(24 \cdot 3)\end{array}$ & $4291(10202)$ & 810 (1379) \\
\hline $\begin{array}{l}\text { SIDRIA-Rome, } \\
\text { Italy }\end{array}$ & 9105 & $\begin{array}{l}44 \cdot 3 \\
(6 \cdot 0)\end{array}$ & $\begin{array}{l}53 \\
(0.58 \%)\end{array}$ & .. &.. & $\begin{array}{l}36 \cdot 5 \\
(5 \cdot 0)\end{array}$ & $\begin{array}{l}16 \cdot 7 \\
(3 \cdot 4)\end{array}$ & $\begin{array}{l}19 \cdot 4 \\
(1.8)\end{array}$ & $2.7(0.5)$ & $39 \cdot 1(9 \cdot 1)$ & $\begin{array}{l}82 \cdot 0 \\
(23 \cdot 9)\end{array}$ & $2956(6728)$ & $1392(2825)$ \\
\hline $\begin{array}{l}\text { EPIC-San } \\
\text { Sebastian, Spain }\end{array}$ & 7464 & $\begin{array}{l}49 \cdot 4 \\
(7 \cdot 7)\end{array}$ & $\begin{array}{l}52 \\
(0.70 \%)\end{array}$ & .. &.. & NA & NA & NA & NA & $23 \cdot 8(6 \cdot 6)$ & $\begin{array}{l}47 \cdot 1 \\
(12 \cdot 5)\end{array}$ & NA & $673(2614)$ \\
\hline $\begin{array}{l}\text { EPIC-Athens, } \\
\text { Greece }\end{array}$ & 4096 & $\begin{array}{l}49 \cdot 0 \\
(11 \cdot 7)\end{array}$ & $\begin{array}{l}18 \\
(0.44 \%)\end{array}$ & $6(0 \cdot 15 \%)$ & .. & $\begin{array}{l}45 \cdot 2 \\
(13 \cdot 7)\end{array}$ & $\begin{array}{l}20 \cdot 8 \\
(2 \cdot 6)\end{array}$ & $\begin{array}{l}20 \cdot 4 \\
(2 \cdot 7)\end{array}$ & $2.3(0.5)$ & $38 \cdot 0(13 \cdot 7)$ & $\begin{array}{l}75 \cdot 5 \\
(41 \cdot 0)\end{array}$ & $9073(12512)$ & $\begin{array}{l}11000 \\
(15000)\end{array}$ \\
\hline \multicolumn{14}{|c|}{ 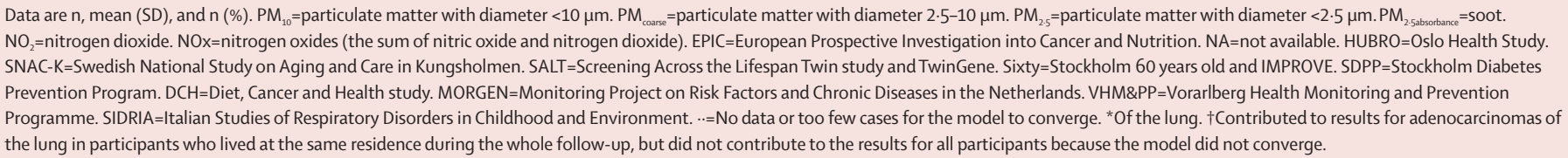 } \\
\hline
\end{tabular}


PE Schwarze PhD, Prof P Nafstad MD); Institute of Health and Society, University of Oslo, Oslo, Norway

(Prof P Nafstad); Institute of Environmental Medicine (Prof U De Faire PhD,

J Penell PhD, M Korek MSc, Prof G Pershagen PhD), Department of Medical Epidemiology and Biostatistics (Prof N L Pedersen PhD),

Department of Molecular Medicine and Surgery (Prof C-G Östenson PhD), and Aging Research Center, Department of Neurobiology, exposure at the baseline address of each cohort member. We also collected information on two indicators of traffic at the residence: traffic intensity (vehicles per day) on the nearest street and total traffic load (vehicle-km driven per day) on all major roads within $100 \mathrm{~m}$.

\section{Statistical analyses}

Proportional hazards Cox regression models were fitted for each cohort, with age as the underlying timescale. Participants were followed up for lung cancer from enrolment until the time of a lung cancer diagnosis or censoring. Participants with a cancer (except nonmelanoma skin cancer) before enrolment were excluded. Censoring was done at the time of death, a diagnosis of

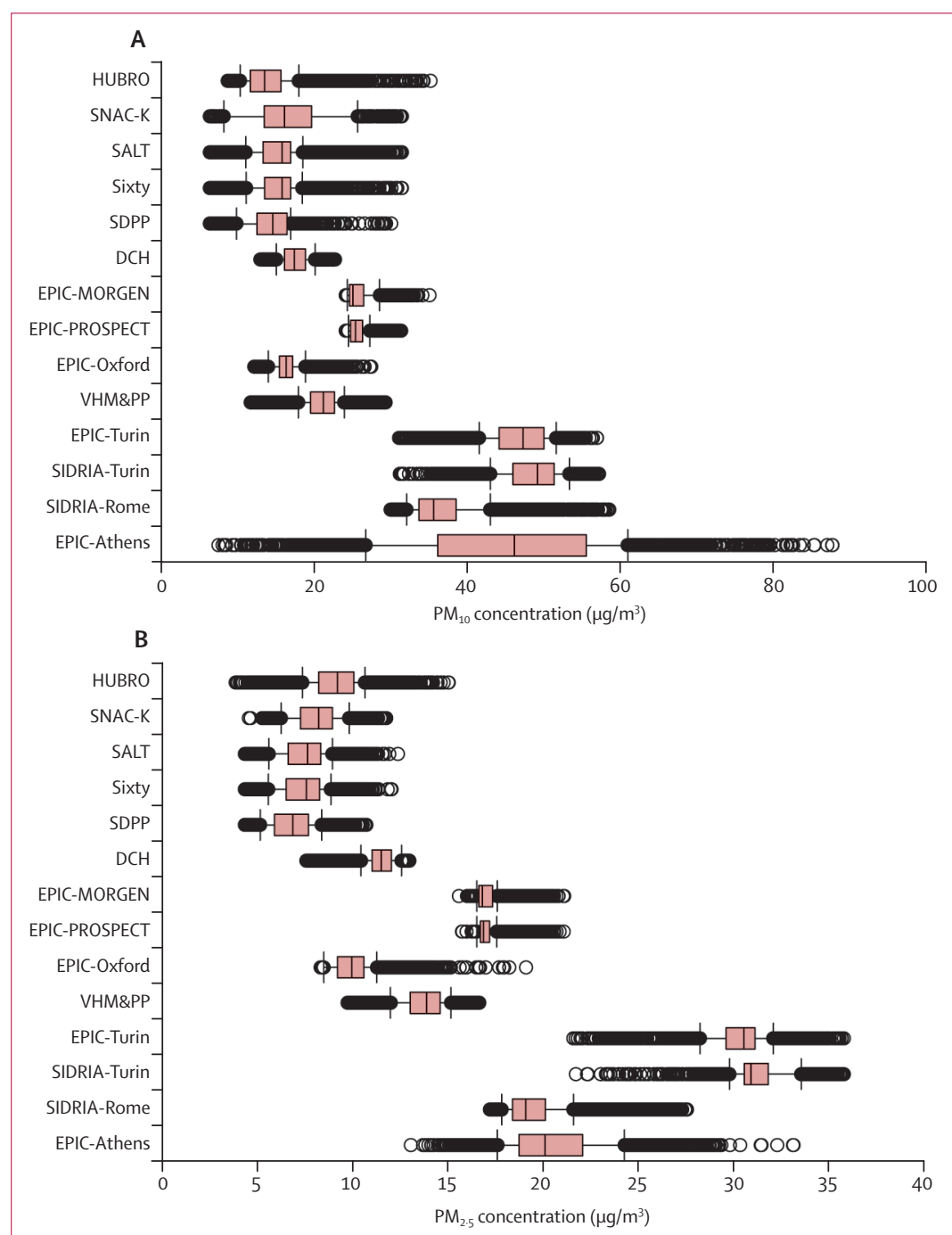

Figure 2: Distribution of particulate matter air pollution at participant addresses in each cohort $\mathrm{PM}_{10}$ concentration (A) and $\mathrm{PM}_{2.5}$ concentration (B) in each of the cohort studies. Pink boxes show median (central vertical line) and 25th and 75th percentiles (ends of box); lines extending from the left of each box show the concentration range from the 10 th to the 25 th percentile; lines extending from the right of each box show the concentration range from the 75 th to the 90 th percentile. The black circles show each concentration below the 10th percentile and above the 90 th percentile. $\mathrm{PM}_{10}=$ particulate matter with diameter $<10 \mu \mathrm{m}$. $\mathrm{PM}_{2.5}=$ particulate matter with diameter $<2.5 \mu \mathrm{m}$. any other cancer (except non-melanoma skin cancer), emigration, disappearance, loss to follow-up for other reasons, or end of follow-up, whichever came first. For the analyses of histological subtypes of lung cancer, cases of different histological subtypes were censored.

Air pollution exposure was analysed as a linear variable in three a-priori specified confounder models. Model 1 included sex, calendar time (year of enrolment; linear), and age (time axis). Model 2 additionally adjusted for smoking status (never, former, or current), smoking intensity, square of smoking intensity, smoking duration, time since quitting smoking, environmental tobacco smoke, occupation, fruit intake, marital status, level of education, and employment status (all referring to baseline). We entered a squared term of smoking intensity because we expected a non-linear association with lung cancer. Model 3 (the main model) further adjusted for area-level socioeconomic status. A cohort was included only if information about age, sex, calendar time, smoking status, smoking intensity, and smoking duration were available.

We assessed individual characteristics as a-priori potential effect modifiers: age ( $<65$ years or $\geq 65$ years), sex, level of education, smoking status, fruit intake ( $<150$ g, 150-300 g, or $\geq 300$ g per day). Age was analysed time dependently. For a few cohorts (HUBRO, Sixty, SDPP) for which there was information about fruit intake in categories such as "a few times per week", "daily", and "several times per day", the lowest category was analysed as less than $150 \mathrm{~g}$ per day, the medium category as 150-300 g per day, and the highest category as 300 g per day or greater.

We undertook several sensitivity analyses and model checks for each cohort, all with confounder model 3 . First, we restricted the analyses to participants who had lived at the baseline address throughout follow-up to minimise misclassification of long-term exposure relevant to the development of lung cancer. Second, we added an indicator of extent of urbanisation to model 3. Third, we tested the linear assumption in the relation between each air pollutant and lung cancer by replacing the linear term with a natural cubic spline with three equally spaced inner knots, and compared the model fit of the linear and the spline models by the likelihood-ratio test. Fourth, to investigate if an association between air pollution and risk for lung cancer was detectable below a-priori defined thresholds, we ran models including only participants exposed to air pollution concentrations below those thresholds.

In the meta-analysis, we used random-effects models to pool the results for cohorts. ${ }^{22} I^{2}$ statistics ${ }^{23}$ and $\mathrm{p}$ values for the $\chi^{2}$ test from Cochran's $Q$ were calculated to investigate the heterogeneity among cohort-specific effect estimates. Effect modification was tested by meta-analysing the pooled estimates from the different strata with the $\chi^{2}$ test of heterogeneity. We assessed the 
robustness of the results by repeating the meta-analysis after exclusion of the two largest cohorts. The proportional hazards assumption of the Cox model was not violated (appendix, p 19).

We used a common STATA script for all analyses, except for spline models, which were fitted with $\mathrm{R}$ software. The versions of software used to analyse individual cohorts are listed in the appendix (pp 2-18).

\section{Role of the funding source}

The sponsors had no role in the study design, data collection, data analysis, data interpretation, or writing of the report. Authors with access to the raw data included JS and AO (EPIC-Umeå), BO (HUBRO), JP (SNAC-K, SALT, Sixty, and SDPP), ZJA (DCH), RB (EPIC-MORGEN and EPIC-PROSPECT), WWX (EPIC-Oxford and EPIC-Varese), GW (VHM\&PP), FR (EPIC-Turin), CG and EM (SIDRIA-Turin), GC (SIDRIA-Rome), IT (EPIC-San Sebastian), and KK (EPIC-Athens). The corresponding author had full access to all analysis results from each cohort and final responsibility for the decision to submit for publication.

\section{Results}

The 17 cohorts in nine European countries that contributed to this study contained 312944 cohort members and contributed 4013131 person-years at risk and 2095 incident lung cancer cases that developed during follow-up (average follow-up was $12 \cdot 8$ years). More details of each cohort, including characteristics of the participants, available variables, and their distribution are provided in the appendix (pp 2-18). Most of the cohort studies recruited participants in the 1990s (appendix, pp 2-18). The number of participants and the number of those who developed cancer varied substantially between cohorts, with the Danish (DCH) and Austrian (VHM\&PP) cohorts contributing more than half the lung cancer cases (table 1). The cohort areas represented a wide range of air pollution concentrations, with three to 12 times higher mean air pollution levels in some southern European areas than in some northern European areas (table 1). The variation in exposure within study areas was substantial (figure 2; appendix pp 26-28). The mean age at enrolment in each cohort ranged from 43 to 73 years (table 1 ).

The meta-analysis showed an association with risk for lung cancer that was statistically significant for $\mathrm{PM}_{10}$ concentration (hazard ratio $[\mathrm{HR}] \quad 1.22 \quad[95 \% \mathrm{CI}$ $1.03-1.45]$ per $\left.10 \mu \mathrm{g} / \mathrm{m}^{3}\right)$ in confounder model 3. For $\mathrm{PM}_{2.5}$ concentration, the $\mathrm{HR}$ was $1.18(0 \cdot 96-1.46)$ per $5 \mathrm{\mu g} / \mathrm{m}^{3}$, and for traffic load at major roads within $100 \mathrm{~m}$ the HR was $1 \cdot 09(0 \cdot 99-1 \cdot 21)$ per 4000 vehicle-km per day in confounder model 3 (table 2). The results from model 1, with adjustment only for age, sex, and calendar time, showed stronger associations; the effect of adjustment was due mainly to the smoking variables. Results of models 2 and 3 showed no association between risk for lung cancer and $\mathrm{NO}_{2}, \mathrm{NOx}$, or traffic intensity at the nearest street (table 2). Restriction to the 14 cohorts for whom estimates of exposure to particulate matter were available gave similar results for $\mathrm{NO}$ (HR 1.01, 95\% CI 0.94-1.09) and NOx (HR 1.03, 0.97-1.10). Figure 3 shows the HRs for each cohort from the meta-analyses for $\mathrm{PM}_{10}$ and $\mathrm{PM}_{2.5}$. Although the HRs varied substantially across cohorts, the $95 \%$ CIs for each cohort always included the overall metaanalysis estimate, and we did not identify any significant heterogeneity between cohorts. The meta-analysis HRs

\begin{tabular}{|c|c|c|c|c|c|c|c|}
\hline & \multirow[t]{2}{*}{ Increase } & \multirow[t]{2}{*}{$\begin{array}{l}\text { Number } \\
\text { of } \\
\text { cohorts }\end{array}$} & \multicolumn{3}{|l|}{$\mathrm{HR}(95 \% \mathrm{Cl})$} & \multicolumn{2}{|c|}{$\begin{array}{l}\text { Measures of heterogeneity } \\
\text { between cohorts } \\
\text { (model 3) }\end{array}$} \\
\hline & & & Model $1^{*}$ & Model $2 \dagger$ & Model $3 \ddagger$ & $P^{2}$ & $\mathrm{p}$ value \\
\hline $\mathrm{PM}_{10}$ & $10 \mu \mathrm{g} / \mathrm{m}^{3}$ & 14 & $1.32(1.12-1.55)$ & $1.21(1.03-1.43)$ & $1.22(1.03-1.45)$ & $0.0 \%$ & 0.83 \\
\hline $\mathrm{PM}_{2.5}$ & $5 \mu \mathrm{g} / \mathrm{m}^{3}$ & 14 & $1 \cdot 34(1.09-1.65)$ & $1.17(0.95-1.45)$ & $1.18(0.96-1.46)$ & $0.0 \%$ & 0.92 \\
\hline $\mathrm{PM}_{\text {coarse }}$ & $5 \mu \mathrm{g} / \mathrm{m}^{3}$ & 14 & $1.19(0.99-1.42)$ & $1.08(0.89-1 \cdot 31)$ & $1.09(0.88-1.33)$ & $33 \cdot 8 \%$ & $0 \cdot 11$ \\
\hline $\mathrm{PM}_{2.5 \mathrm{abs} \text { sorbance }}$ & $10^{-5} / \mathrm{m}$ & 14 & $1.25(1.05-1.50)$ & $1 \cdot 09(0 \cdot 87-1 \cdot 37)$ & $1.12(0.88-1.42)$ & $19.0 \%$ & 0.25 \\
\hline $\mathrm{NO}_{2}$ & $10 \mu \mathrm{g} / \mathrm{m}^{3}$ & 17 & $1.07(1.00-1.14)$ & $0.99(0.93-1.06)$ & $0.99(0.93-1.06)$ & $0.0 \%$ & 0.70 \\
\hline NOx & $20 \mu \mathrm{g} / \mathrm{m}^{3}$ & 17 & $1.08(1.02-1.14)$ & $1.01(0.95-1.06)$ & $1.01(0.95-1.07)$ & $0.0 \%$ & 0.62 \\
\hline Traffic density on nearest road & $\begin{array}{l}5000 \text { vehicles } \\
\text { per day }\end{array}$ & 15 & $1.02(0.98-1.06)$ & $1.00(0.97-1.04)$ & $1.00(0.97-1.04)$ & $0.0 \%$ & 0.90 \\
\hline $\begin{array}{l}\text { Traffic load on major roads } \\
\text { within } 100 \mathrm{~m}\end{array}$ & $\begin{array}{l}4000 \text { vehicle-km } \\
\text { per day }\end{array}$ & 16 & $1 \cdot 10(1 \cdot 00-1 \cdot 21)$ & $1.07(0.97-1.18)$ & $1.09(0.99-1.21)$ & $0.0 \%$ & 0.92 \\
\hline \multicolumn{8}{|c|}{ 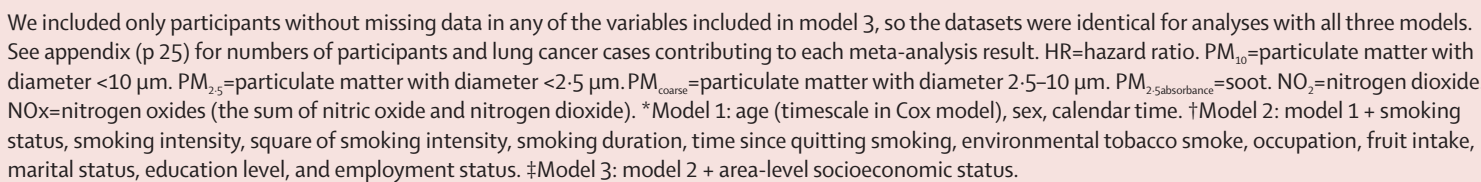 } \\
\hline
\end{tabular}

Care Sciences and Society (L Fratiglioni PhD), Karolinska Institute, Stockholm, Sweden; Department of Environmental Science, Aarhus University, Roskilde, Denmark

(T Ellermann PhD); Cancer Epidemiology Unit, Nuffield Department of Clinical Medicine, University of Oxford, Oxford, UK (Prof T J Key DPhil): Agency for Preventive and Social Medicine, Bregenz, Austria (H Concin MD, G Nagel); INSERM, Centre for Research in Epidemiology and Population Health, U 1018, Nutrition, Hormones and Women's Health Team, Villejuif, France (A Vilier MSc); University Paris Sud, UMRS 1018, Villejuif, France (A Vilier); Institut Gustave-Roussy, Villejuif France (A Vilier); Epidemiology and Prevention Unit, Fondazione IRCCS Istituto Nazionale dei Tumori, Milan, Italy (S Grioni BSc, V Krogh MD), Department of Epidemiology and Public Health, Swiss Tropical and Public Health Institute, University of Basel, Basel, Switzerland (M-YTsai PhD); Department of Environmental and Occupational Health Sciences, University of Washington, Seattle, WA, USA (M-Y Tsai); Human Genetics Foundation, Turin, Italy (F Ricceri PhD); Unit of Cancer Epidemiology, AO Citta' della Salute e della Scienza-University of Turin and Center for Cancer Prevention, Turin, Italy (C Sacerdote PhD, ( Galassi MD, E Migliore MSc); Environmental Health Reference Centre-Regional Agency for Environmental Prevention of Emilia-Romagna, Modena, Italy (A Ranzi PhD); Health Division of Gipuzkoa Research Institute of BioDonostia, Donostia-San Sebastian, Spain (ITamayo MSc); CIBERESP, Consortium for Biomedical Research in Epidemiology and Public Health, Madrid, Spain (PAmiano MSc, M Dorronsoro MD); and Hellenic Health Foundation, Athens, Greece (Prof A Trichopoulou) Correspondence to: Dr Ole Raaschou-Nielsen, Danish Cancer Society Research Center, 2100 Copenhagen, Denmark ole@cancer.dk 


\begin{tabular}{|c|c|c|c|c|c|}
\hline \multicolumn{4}{|l|}{$\begin{array}{l}\text { A } \\
\text { Study }\end{array}$} & \multirow{2}{*}{$\begin{array}{l}\mathrm{HR}(95 \% \mathrm{Cl}) \\
1.06(0.50-2.27)\end{array}$} & \multirow{2}{*}{$\begin{array}{c}\text { Weight (\%) } \\
4.92\end{array}$} \\
\hline HUBRO & & $\rightarrow$ & & & \\
\hline SNAC-K & $\longrightarrow$ & & & $0.89(0.37-2.12)$ & 3.71 \\
\hline SALT & - & & & $0.69(0.32-1.47)$ & 4.82 \\
\hline Sixty & & $\rightarrow$ & & $1.63(0.72-3.67)$ & $4 \cdot 29$ \\
\hline SDPP & & $\rightarrow$ & & $1.17(0.40-3.40)$ & 2.48 \\
\hline $\mathrm{DCH}$ & & $\because$ & & $1.10(0.69-1.76)$ & $12 \cdot 77$ \\
\hline EPIC-MORGEN & & : & & $0.36(0.08-1.57)$ & 1.33 \\
\hline EPIC-PROSPECT & & & $\rightarrow$ & $1.89(0.35-10.31)$ & 0.98 \\
\hline EPIC-Oxford & & 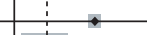 & & $1.64(0.50-5.39)$ & 1.99 \\
\hline VHM\&PP & & & & $1.20(0.87-1.66)$ & 27.70 \\
\hline EPIC-Turin & & & & $1.45(0.69-3.04)$ & $5 \cdot 11$ \\
\hline SIDRIA-Turin & & & & $1.41(0.46-4.31)$ & $2 \cdot 27$ \\
\hline SIDRIA-Rome & & & & $1.35(0.85-2.16)$ & 12.85 \\
\hline EPIC-Athens & & - & & $1.55(1.00-2 \cdot 40)$ & 14.79 \\
\hline Overall $\left(l^{2}=0.0 \%, p=0.828\right)$ & & & & $1.22(1.03-1.45)$ & $100 \cdot 00$ \\
\hline 0.25 & 0.5 & 2 & $\begin{array}{l}1 \\
4\end{array}$ & & \\
\hline \multicolumn{6}{|l|}{ B } \\
\hline HUBRO & - & & & $0.83(0.35-2 \cdot 00)$ & 5.74 \\
\hline SNAC-K & & & & $0.73(0.12-4.37)$ & $1 \cdot 38$ \\
\hline SALT & & & $\rightarrow$ & $1.24(0.23-6 \cdot 76)$ & 1.54 \\
\hline Sixty & & & - & $1.56(0.41-5.98)$ & $2 \cdot 45$ \\
\hline SDPP & & & $\rightarrow$ & $2.01(0.40-10.01)$ & 1.71 \\
\hline DCH & - & & & $0.91(0.52-1.60)$ & 14.09 \\
\hline EPIC-MORGEN & & & & $0 \cdot 49(0.08-3 \cdot 21)$ & 1.26 \\
\hline EPIC-PROSPECT & & & $\rightarrow$ & $1.09(0.17-6.99)$ & $1 \cdot 28$ \\
\hline EPIC-Oxford & & & & $0.53(0.15-1.91)$ & 2.73 \\
\hline VHM\&PP & & & & $1.32(0.97-1.81)$ & $44 \cdot 56$ \\
\hline EPIC-Turin & & & & $1.60(0.67-3 \cdot 81)$ & 5.87 \\
\hline SIDRIA-Turin & & & $\rightarrow$ & $1.94(0.54-7.00)$ & $2 \cdot 67$ \\
\hline SIDRIA-Rome & & $\rightarrow$ & & $1.33(0.69-2.58)$ & $10 \cdot 12$ \\
\hline EPIC-Athens & $\longrightarrow$ & & & $0.90(0.34-2.40)$ & 4.58 \\
\hline Overall $\left(l^{2}=0.0 \%, \mathrm{p}=0.922\right)$ & & & & $1.18(0.96-1.46)$ & $100 \cdot 00$ \\
\hline 0.25 & 0.5 & 1 & 4 & & \\
\hline
\end{tabular}

Figure 3: Risk for lung cancer according to concentration of particulate matter in each cohort study HRs for lung cancer according to $\mathrm{PM}_{10}$ concentration ( $\mathrm{A}$ ) and $\mathrm{PM}_{25}$ concentration (B) in each of the cohort studies, based on confounder model 3 . Weights are from random effects analysis. Datapoints show HR; lines show $95 \% \mathrm{Cl}$; boxes show the weight with which each cohort contributed to the overall $\mathrm{HR}$; vertical dashed line shows overall HR. $\mathrm{HR}=$ hazard ratio. $\mathrm{PM}_{10}=$ particulate matter with diameter $<10 \mu \mathrm{m} . \mathrm{PM}_{25}=$ particulate matter with diameter $<2.5 \mu \mathrm{m}$.
Squamous-cell carcinomas were not significantly associated with particulate matter air pollution.

Restriction of participants to those exposed to air pollution below several predefined thresholds for particulate matter concentrations (including below European Union air quality limit values for $\mathrm{PM}_{10}$ [40 $\left.\mathrm{\mu g} / \mathrm{m}^{3}\right]$ and $\left.\mathrm{PM}_{2.5}\left[25 \mu \mathrm{g} / \mathrm{m}^{3}\right]\right)$ provided consistently raised HRs, although the $95 \%$ CIs crossed unity (table 4). This finding is complemented by the results of the spline models (appendix p 22), showing that the association between air pollution and risk for lung cancer did not deviate significantly from linear.

We noted no clear differences between the HRs for lung cancer associated with $\mathrm{PM}_{10}$ and $\mathrm{PM}_{2.5}$ according to sex, age, level of education, smoking status, or fruit intake (appendix p 23), with widely overlapping CIs for the effect modifier levels; all the $\mathrm{p}$ values for interaction were 0.19 or higher. We also noted raised HRs for lung cancer in association with $\mathrm{PM}_{10}$ and $\mathrm{PM}_{2.5}$ in neversmokers (appendix p 23).

The HRs for lung cancer in association with $\mathrm{PM}_{10}$ and $\mathrm{PM}_{2.5}$ were virtually identical before and after exclusion of the two largest cohorts (which contributed most of the lung cancer cases; appendix p 24). Adjustment for extent of urbanisation, which could be done in seven cohorts, led to a small change in the HR for $\mathrm{PM}_{10}$, which was, however, due almost entirely to selection of contributing cohorts and not to adjustment for urbanisation per se (appendix p 24).

With decreasing air pollution concentrations and contrasts over time, risk estimates based on recent contrast might be too high. We investigated this by back-extrapolating contrast in two cohorts with long-term $\mathrm{PM}_{2.5}$ monitoring, and in seven cohorts with long-term $\mathrm{PM}_{10}$ monitoring. Results were identical for $\mathrm{PM}_{2.5}$ and only slightly lower for $\mathrm{PM}_{10}$ when using the back-extrapolated contrasts (appendix p 19).

\section{Discussion}

This analysis of 17 European cohort studies shows associations between residential exposure to particulate matter air pollution at enrolment and the risk for lung cancer. The associations were stronger for adenocarcinomas of the lung and in participants who lived at their enrolment address throughout follow-up.

The strengths of our study include the use of 17 cohort studies in several locations in Europe with very different air pollution exposure levels and also the use of standardised protocols for exposure assessment and data analysis. A comprehensive set of pollutants was assessed, by contrast with many previous studies; few European studies have assessed particulate matter air pollution (panel). Individual exposure assessment was based on actual measurements made in the development of land-use regression models for the detection of withinarea contrasts. The study benefits from standardised exposure assessment, a large number of participants, 


\begin{tabular}{|c|c|c|c|c|c|}
\hline & \multirow[t]{2}{*}{ Number of cohorts } & \multicolumn{2}{|c|}{$\begin{array}{l}\mathrm{HR}(95 \% \mathrm{Cl}) \text { for histological cancer } \\
\text { subtype analysis }\end{array}$} & \multicolumn{2}{|c|}{ HR $(95 \% \mathrm{Cl})$ for standard analysis* } \\
\hline & & $\mathrm{PM}_{10}$ & $\mathrm{PM}_{2.5}$ & $\mathrm{PM}_{10}$ & $\mathrm{PM}_{2.5}$ \\
\hline \multicolumn{6}{|l|}{ All participants } \\
\hline All lung cancers & $14 \dagger$ & $1.22(1.03-1.45)$ & $1.18(0.96-1.46)$ & $1.22(1.03-1.45)$ & $1.18(0.96-1.46)$ \\
\hline Adenocarcinomas & $11 \ddagger$ & $1 \cdot 51(1 \cdot 10-2 \cdot 08)$ & $1.55(1.05-2 \cdot 29)$ & $1.22(1.01-1.47)$ & $1.16(0.92-1.45)$ \\
\hline Squamous-cell carcinomas & 75 & $0.84(0.50-1.40)$ & $1.46(0.43-4.90)$ & $1.19(0.94-1.51)$ & $1.18(0.91-1.52)$ \\
\hline \multicolumn{6}{|c|}{ Participants who did not change residence } \\
\hline All lung cancers & 10 的 & $1.48(1.16-1.88)$ & $1.33(0.98-1.80)$ & $1.22(1.02-1.46)$ & $1.20(0.96-1.51)$ \\
\hline Adenocarcinomas & $8 \|$ & $2 \cdot 27(1 \cdot 32-3 \cdot 91)$ & $1.65(0.93-2.95)$ & $1.19(0.98-1.45)$ & $1.17(0.92-1.49)$ \\
\hline Squamous-cell carcinomas & $3^{* *}$ & $0.64(0.28-1.48)$ & $0.65(0.16-2.57)$ & $1.21(0.94-1.55)$ & $1.22(0.93-1.60)$ \\
\hline \multicolumn{6}{|c|}{ 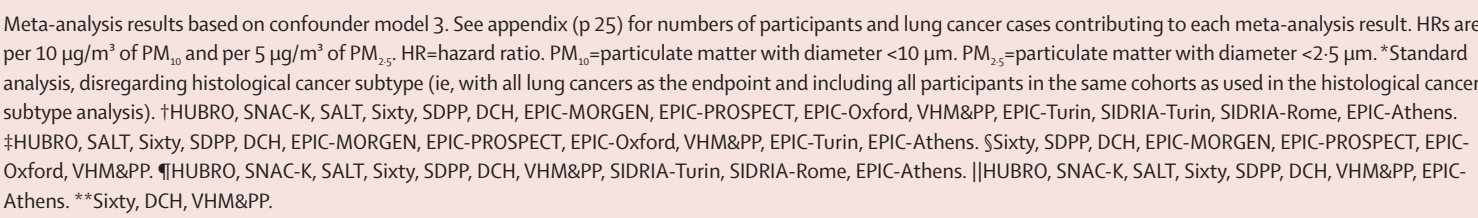 } \\
\hline
\end{tabular}

information about potential confounders, and a virtually complete follow-up. Only one cohort (EPIC-Athens) used active follow-up with a loss of follow-up information for $335(6 \cdot 5 \%)$ of the participants; the other cohorts reported complete follow-up by use of registries and administrative systems. The loss of follow-up in the Athens cohort is slight and we see no reason why it should be related to concentrations of air pollution, which could imply risk for bias.

Most results from previous cohort studies of ambient particulate matter air pollution and lung cancer incidence or mortality in general populations showed associations that were statistically significant or of borderline significance, ${ }^{2,5-9,11,26,27}$ whereas two studies reported no such association. ${ }^{13,28}$ The present study, one of the largest of its kind with 2095 lung cancer cases, estimated an HR of $1.40 \quad(95 \%$ CI $0 \cdot 92-2 \cdot 13)$ per $10 \mu \mathrm{g} / \mathrm{m}^{3}$ of $\mathrm{PM}_{2.5}$ (equivalent to $\mathrm{HR} 1 \cdot 18$, $0.96-1.46$ per $5 \mu \mathrm{g} / \mathrm{m}^{3}$ ), which is similar to the Harvard Six Cities study ${ }^{8}$ estimate in a US cohort (351 cases) of $1 \cdot 37(1 \cdot 07-1 \cdot 75)$ per $10 \mu \mathrm{g} / \mathrm{m}^{3}$ and that from a Canadian study (HR 1.29, 0.95-1.76; 2390 cases), ${ }^{29}$ but higher than the estimate from an American Cancer Society study (HR 1.14 1.04-1.23), ${ }^{2}$ and from studies in the Netherlands (HR 0.81, 0.63-1.04; 1940 cases), ${ }^{13}$ Japan (HR 1.24, 1.12-1.37; 518 cases), ${ }^{5}$ China (HR 1.03, 1.00-1.07; 624 cases), ${ }^{6}$ and Italy (HR 1.05, 1.01-1.10; 12208 cases). ${ }^{11}$ The CIs of these estimates, however, overlap with ours, so the differences could be due to random variation. Previously estimated associations with $\mathrm{PM}_{10}$ differ more widely than those with $\mathrm{PM}_{2.5}$. Our estimated HR of 1.22 per $10 \mu \mathrm{g} / \mathrm{m}^{3}$ of $\mathrm{PM}_{10}(1 \cdot 03-1 \cdot 45)$ is in line with that of a recent study in New Zealand (HR 1.15, 1.04-1.26; 1686 cases), ${ }^{7}$ higher than that in a previous European study (HR 0.91, 0.70-1.18;

\begin{tabular}{|c|c|c|c|}
\hline & $\begin{array}{l}\text { Number of } \\
\text { cohorts }\end{array}$ & $\begin{array}{l}\mathrm{HR}(95 \% \mathrm{Cl}) \text { for threshold } \\
\text { analyses }\end{array}$ & $\begin{array}{l}\mathrm{HR}(95 \% \mathrm{Cl}) \text { for standard } \\
\text { analyses } \dagger\end{array}$ \\
\hline \multicolumn{4}{|l|}{$\mathrm{PM}_{10}$} \\
\hline $15 \mu \mathrm{g} / \mathrm{m}^{3}$ & $5 \ddagger$ & $1 \cdot 34(0.51-3 \cdot 52)$ & $1.21(0.87-1.68)$ \\
\hline $20 \mu \mathrm{g} / \mathrm{m}^{3}$ & $8 s$ & $1 \cdot 31(0.94-1.82)$ & $1.13(0.92-1.40)$ \\
\hline $25 \mu \mathrm{gg} / \mathrm{m}^{3}$ & 10 㐿 & $1.17(0.93-1.47)$ & $1.12(0.91-1 \cdot 38)$ \\
\hline $30 \mu \mathrm{g} / \mathrm{m}^{3}$ & $10 \pi$ & $1.13(0.92-1.40)$ & $1.12(0.91-1.38)$ \\
\hline $35 \mu \mathrm{gg} / \mathrm{m}^{3}$ & $11 \|$ & $1.11(0.90-1 \cdot 37)$ & $1.15(0.95-1.39)$ \\
\hline $40 \mu \mathrm{g} / \mathrm{m}^{3}$ & $12^{* *}$ & $1.13(0.92-1.39)$ & $1.17(0.97-1.41)$ \\
\hline No threshold & 14 (all)†† & $1.22(1.03-1.45)$ & $1.22(1.03-1.45)$ \\
\hline \multicolumn{4}{|l|}{$\mathrm{PM}_{2.5}$} \\
\hline $10 \mu \mathrm{g} / \mathrm{m}^{3}$ & $6 \neq \ddagger$ & $1.20(0.55-2.66)$ & $0.97(0.63-1.49)$ \\
\hline $15 \mu \mathrm{g} / \mathrm{m}^{3}$ & $8 \$ \$$ & $1.11(0.85-1.45)$ & $1.15(0.90-1.47)$ \\
\hline $20 \mu \mathrm{g} / \mathrm{m}^{3}$ & 11बा & $1.14(0.90-1.45)$ & $1.16(0.92-1.45)$ \\
\hline $25 \mu \mathrm{g} / \mathrm{m}^{3}$ & 11बा & $1.13(0.90-1.43)$ & $1.16(0.92-1.45)$ \\
\hline No threshold & 14 (all)†† & $1.18(0.96-1.46)$ & $1.18(0.96-1.46)$ \\
\hline
\end{tabular}

Meta-analysis results based on confounder model 3. See appendix ( 1 25) for numbers of participants and lung cancer cases contributing to each meta-analysis result. HRs are per $10 \mu \mathrm{g} / \mathrm{m}^{3}$ of PMM ${ }_{10}$ and per $5 \mu \mathrm{gg} / \mathrm{m}^{3}$ of $P M_{25}$. HR=hazard ratio. $\mathrm{PM}_{10}=$ particulate matter with diameter $<10 \mu \mathrm{m} . \mathrm{PM}_{25}=$ particulate matter with diameter $<2.5 \mu \mathrm{m}$. ${ }^{*}$ Participants living at addresses (at baseline) with air pollution above these thresholds were excluded from the analysis. †Standard analysis, disregarding thresholds (ie, including all participants in the same cohorts as used in the threshold analysis). fHUBRO, Sixty, SDPP, DCH, EPIC-Oxford. SHUBRO, SNAC-K, SALT, Sixty, SDPP, DCH, EPIC-Oxford, VHM\&PP. IIHUBRO, SNAC-K, SALT, Sixty, SDPP, DCH, EPIC-MORGEN, EPIC-PROSPECT, EPIC-Oxford, VHMEPP. ||HUBRO, SNAC-K, SALT, Sixty, SDPP, DCH, EPIC-MORGEN, EPIC-PROSPECT, EPIC-OXford, VHM\&PP, SIDRIA-Rome. **HUBRO, SNAC-K, SALT, Sixty, SDPP, DCH, EPIC-MORGEN, EPIC-PROSPECT, EPIC-Oxford, VHM\&PP, EPIC-Turin, SIDRIA-Rome. ††HUBRO, SNAC-K, SALT, Sixty, SDPP, DCH, EPIC-MORGEN, EPIC-PROSPECT, EPIC-Oxford, VHM\&PP, EPIC-Turin, SIDRIA-Turin, SIDRIA-Rome, EPIC-Athens. ¥¥SNAC-K, SALT, Sixty, SDPP, DCH, EPIC-Oxford. SSHUBRO, SNAC-K, SALT, Sixty, SDPP, DCH, EPIC-Oxford, VHM\&PP. TाभHUBRO, SNAC-K, SALT, Sixty, SDPP, DCH, EPIC-MORGEN, EPIC-PROSPECT, EPIC-Oxford, VHM\&PP, SIDRIA-Rome.

Table 4: Associations between $\mathrm{PM}_{10}$ and $\mathrm{PM}_{25}$ and risk for lung cancer, according to air pollution thresholds*

271 cases) ${ }^{28}$ and lower than those in studies in the USA (HR 5.21, 1.94-13.99; 36 cases) per $24 \mu \mathrm{g} / \mathrm{m}^{3} \mathrm{PM}_{10}{ }^{26}$ and Germany (HR 1.84, 1.23-2.74; 41 cases) per $7 \mu \mathrm{g} / \mathrm{m}^{3} \mathrm{PM}_{10}{ }^{.}$In most of the previous studies, exposure was monitored at a central site; few estimated exposure at individual addresses, as was done in our study. 
Panel: Research in context

\section{Systematic review}

We reviewed the scientific literature up to May, 2007, when our grant proposal was submitted to the European Union. We searched the PubMed and Embase databases for articles and reviews published in English with the search terms "air pollution and lung cancer" and "ambient air and lung cancer". A brief description of the findings of our scientific literature review was part of the study proposal. Two published reviews from the period immediately before 2007 were used as a basis of our scientific literature review. ${ }^{24,25}$ At the time of the inception of our study, some studies had already provided evidence for an association between air pollution and lung cancer risk, but they had limitations: small size of some of the cohort studies; poor retrospective exposure assessment; absence of or limited information about potential confounders; and mortality used instead of lung cancer incidence as outcome.

\section{Interpretation}

Our study supports the role of ambient particulate matter air pollution in the development of lung cancer even at concentrations below current European Union limit values. Our study overcomes several limitations of previous studies, having a large sample size, broad European coverage, retrospective exposure assessment, adjustment for a wide range of potential confounders, and incident lung cancer as the outcome. Particulate matter air pollution is ubiquitous, and on the basis of our results, further reductions in particulate matter air pollution can be expected to reduce the number of lung cancer cases in Europe.

Of the four major histological subtypes of lung cancer, adenocarcinoma is the only one that also develops in a substantial number of non-smokers, ${ }^{30}$ so this subgroup is useful to assess for causes other than smoking, compared with, for example, patients with squamous-cell carcinomas. Such causes might include two groups of carcinogenic air pollutants: polycyclic aromatic hydrocarbons and N-nitroso compounds such as nitrosamines. Dissemination of low-tar filter cigarettes has been hypothesised as a cause of the relative increases in incidence rates of adenocarcinomas and decrease in squamous-cell carcinomas of the lung in the USA because the smoke has a lower content of polycyclic aromatic hydrocarbons, which are thought to be associated with squamous-cell carcinoma, and a higher content of nitrates and toxic agents formed from NOx such as nitrosamines, which are associated with adenocarcinomas. ${ }^{15,16}$ Studies of time trends and geographical correlations have suggested that ambient air pollution might also have affected the incidence of adenocarcinomas, ${ }^{16,17}$ whereas one study suggested an association between air pollution and squamous-cell carcinomas of the lung. ${ }^{14}$ The present study showed associations between air pollution and adenocarcinomas of the lung, but not squamous-cell carcinomas. This result suggests that air pollution with nitrates and toxic agents formed from NOx such as nitrosamines might be more important for risk for lung cancer than polycyclic aromatic hydrocarbons in the air. The concentration of polycyclic aromatic hydrocarbons in the air has decreased substantially in many cities in developed countries throughout the past three to four decades. ${ }^{31}$

Our study has some limitations. The effects of single air pollutants are difficult to disentangle in an epidemiological study because pollutants are part of complex mixtures; however, it seems likely that particulate matter is the most important component for cancer risk. In agreement with this notion, diesel engine exhaust was recently classified as a human carcinogen by the International Agency for Research on Cancer. ${ }^{32}$ Ambient air pollution contains several known carcinogens and particulate matter with absorbed polycyclic aromatic hydrocarbons, transition metals, and other substances is capable of causing oxidative stress, inflammation, and direct and indirect genotoxicity. ${ }^{33,34}$ Associations with particulate matter rather than with NOx thus seem to be plausible.

We used land-use regression models to estimate exposure at the baseline address; however, even the best exposure models incorporate some degree of misclassification. Any misclassification is expected to be non-differential and consequently not to create artificial associations. The uncertainty of the estimated exposure, however, is expected to affect the precision of the estimated HRs (appendix, pp 19). We used data on air pollution for 2008-11 in the development of our land-use regression models but applied them to addresses of participants at baseline (mainly 10-15 years earlier). Results of recent research in Rome, the Netherlands, and Vancouver showed that the spatial distribution of air pollution is stable over 10 -year periods, ${ }^{35}$ another study showed high correlations between traffic intensities in 1986 and 1996 on Dutch streets, ${ }^{36}$ and finally, spatial models for black smoke in the UK provided reasonable predictions, even going back to the $1960 \mathrm{~s} .{ }^{37}$ In our study, exposure was assessed at the enrolment address; relocation during follow-up might have led to misclassification of the exposure relevant to later development of lung cancer. Our results show stronger associations between air pollution and the risk for lung cancer in people who lived at the same address throughout follow-up. The latency for lung cancer can be several decades; ${ }^{38}$ our results suggest that more recent exposure to air pollution is also important in the development of lung cancer.

The cohort-specific analyses consistently identified smoking-related variables as the most important confounders, in accordance with the fact that smoking is the most important risk factor for lung cancer. Information about smoking variables was available for 
all the cohorts, and we would expect only weak confounding, if any, from exposure to environmental tobacco smoke and the other variables listed in the appendix ( $p$ 21). Radon in the residence is an additional potential confounder, but information about radon was not available for any cohort. Radon is probably inversely associated with air pollution concentrations, because radon concentrations are generally low in apartments, which are common in city areas with higher air pollution concentrations. Thus, if confounding by residential radon occurred, we would expect it to lower the HRs for lung cancer in association with air pollution. Although we adjusted thoroughly for smoking in all cohorts, we cannot rule out potential residual confounding, because data for smoking were obtained at enrolment, and we did not account for changes in smoking habits during follow-up. The association was, however, mainly with adenocarcinoma. If residual confounding had occurred, squamous-cell carcinomas should also have been associated with air pollution.

Data for previous lung disease were not obtained, which is a potential weakness of our study because previous lung disease might be associated with both air pollution concentrations and the risk for lung cancer.

The HRs for lung cancer were similar with and without restriction to participants below most of the predefined threshold values, suggesting that exposure of populations to particulate matter air pollution even at concentrations below the existing European Union air quality limit values for $\mathrm{PM}_{10}\left(40 \mu \mathrm{g} / \mathrm{m}^{3}\right)$ and $\mathrm{PM}_{2.5}\left(25 \mu \mathrm{g} / \mathrm{m}^{3}\right)$ might increase the risk for lung cancer. How widely the overall risk estimates from this meta-analysis can be generalised to all European populations is uncertain, but the absence of significant heterogeneity among the HRs obtained for the single cohorts suggests that the overall estimate can be generalised.

In conclusion, this very large multicentre study shows an association between exposure to particulate matter air pollution and the incidence of lung cancer, in particular adenocarcinoma, in Europe, adding substantially to the weight of the epidemiological evidence.

\section{Contributors}

OR-N contributed to design, exposure assessment, and interpretation and drafted the manuscript; ZJA contributed to design, the statistical script, and data analyses; RB and KD contributed to design, exposure assessment, the statistical script, and data analyses; ES and MSt contributed to the statistical script; GW contributed to the statistical script and data analyses; $\mathrm{BH}$ contributed to the statistical script; PF, MJN, LM, MK, KTE, TE, ME, KM, MW, KdH, M-YT, AR, and CBad contributed to exposure assessment; $\mathrm{BB}, \mathrm{KK}$, and PV contributed to design; WWX contributed to design and data analyses; JS, AO, BO, JP, MSø, AV, FR, EM, and IT contributed to data analyses; BF, PES, PN, UDF, NLP, C-GÖ, LF, GP, ATj, PHP, BB-d-M, TJK, HC, GN, SG, VK, CS, FF, PA, MD, and ATr provided local cohort data; CG and GC contributed to exposure assessment and data analyses; GH contributed to design, exposure assessment, and the statistical script. All authors contributed to critical reading of and comments about the manuscript and interpretation of data, and approved the final draft.

Conflicts of interest

We declare that we have no conflicts of interest.

\section{Acknowledgments}

This study was funded by the European Community's Seventh Framework Programme (FP7/2007-2011) under grant agreement number 211250.

\section{References}

1 Spitz MR, Wu X, Wilkinson A, Wei Q. Cancer of the lung. In: Schottenfeld D, Fraumeni JF Jr, eds. Cancer epidemiology and prevention, 3rd edn. Oxford: Oxford University Press, 2006: 638-58.

2 Pope III CA, Burnett RT, Thun MJ, et al. Lung cancer, cardiopulmonary mortality, and long-term exposure to fine particulate air pollution. JAMA 2002; 287: 1132-41.

3 Nafstad P, Haheim LL, Oftedal B, et al. Lung cancer and air pollution: a 27 year follow up of 16209 Norwegian men. Thorax 2003; 58: 1071-76.

4 Raaschou-Nielsen O, Andersen ZJ, Hvidberg M, et al. Lung cancer incidence and long-term exposure to air pollution from traffic. Environ Health Perspect 2011; 119: 860-65.

5 Katanoda K, Sobue T, Satoh H, et al. An association between longterm exposure to ambient air pollution and mortality from lung cancer and respiratory diseases in Japan. J Epidemiol 2011; 21: 132-43.

6 Cao J, Yang C, Li J, et al. Association between long-term exposure to outdoor air pollution and mortality in China: a cohort study. J Hazard Mater 2011; 186: 1594-600.

7 Hales S, Blakely T, Woodward A. Air pollution and mortality in New Zealand: cohort study. J Epidemiol Community Health 2012 66: 468-73.

8 Lepeule J, Laden F, Dockery D, Schwartz J. Chronic exposure to fine particles and mortality: an extended follow-up of the Harvard Six Cities study from 1974 to 2009. Environ Health Perspect 2012; 120: $965-70$

9 Heinrich J, Thiering E, Rzehak P, et al. Long-term exposure to $\mathrm{NO}_{2}$ and $\mathrm{PM}_{10}$ and all-cause and cause-specific mortality in a prospective cohort of women. Occup Environ Med 2012; 70: 179-86.

10 Yorifuji T, Kashima S, Tsuda T, et al. Long-term exposure to traffic-related air pollution and the risk of death from hemorrhagic stroke and lung cancer in Shizuoka, Japan. Sci Total Environ 2013; 443: 397-402.

11 Cesaroni G, Badaloni C, Gariazzo C, et al. Long-term exposure to urban air pollution and mortality in a cohort of more than a million adults in Rome. Environ Health Perspect 2013; 121: 324-31.

12 Yorifuji T, Kashima S, Tsuda T, et al. Long-term exposure to traffic-related air pollution and mortality in Shizuoka, Japan. Occup Environ Med 2010; 67: 111-17.

13 Beelen R, Hoek G, van den Brandt PA, et al. Long-term exposure to traffic-related air pollution and lung cancer risk. Epidemiology 2008; 19: 702-10.

14 Raaschou-Nielsen $\mathrm{O}$, Bak $\mathrm{H}$, Sorensen $\mathrm{M}$, et al. Air pollution from traffic and risk for lung cancer in three Danish cohorts. Cancer Epidemiol Biomarkers Prev 2010; 19: 1284-91.

15 Gabrielson E. Worldwide trends in lung cancer pathology. Respirology 2006; 11: 533-38.

16 Chen F, Cole P, Bina WF. Time trend and geographic patterns of lung adenocarcinoma in the United States, 1973-2002. Cancer Epidemiol Biomarkers Prev 2007; 16: 2724-29.

17 Chen F, Jackson H, Bina WF. Lung adenocarcinoma incidence rates and their relation to motor vehicle density. Cancer Epidemiol Biomarkers Prev 2009; 18: 760-64.

18 Cyrys J, Eeftens M, Heinrich J, et al. Variation of $\mathrm{NO}_{2}$ and $\mathrm{NOx}$ concentrations between and within 36 European study areas: results from the ESCAPE study. Atmos Environ 2012; 62: 374-90.

19 Eeftens M, Tsai M-Y, Ampe C, et al. Spatial variation of PM2.5, PM10 and PM2.5 absorbance and PM coarse concentrations between and within 20 European study areas and the relationship with $\mathrm{NO}_{2}-$ results of the ESCAPE project. Atmos Environ 2012; 62: 303-17.

20 Eeftens M, Beelen R, de Hoogh K, et al. Development of land use regression models for $\mathrm{PM}(2.5), \mathrm{PM}(2.5)$ absorbance, $\mathrm{PM}(10)$ and PM(coarse) in 20 European study areas; results of the ESCAPE project. Environ Sci Technol 2012; 46: 11195-205.

21 Beelen R, Hoek G, Vienneau D, et al. Development of $\mathrm{NO}_{2}$ and NOx land use regression models for estimating air pollution exposure in 36 study areas in Europe-the ESCAPE project. Atmos Environ 2013; 72: 10-23. 
22 DerSimonian R, Laird N. Meta-analysis in clinical trials. Control Clin Trials 1986; 7: 177-88.

23 Higgins JP, Thompson SG. Quantifying heterogeneity in a meta-analysis. Stat Med 2002; 21: 1539-58.

24 Vineis P, Forastiere F, Hoek G, Lipsett M. Outdoor air pollution and lung cancer: recent epidemiologic evidence. Int J Cancer 2004; 111: $647-52$.

25 Vineis P, Husgafvel-Pursiainen K. Air pollution and cancer: biomarker studies in human populations. Carcinogenesis 2005; 26: 1846-55.

26 Beeson WL, Abbey DE, Knutsen SF. Long-term concentrations of ambient air pollutants and incident lung cancer in California adults: results from the AHSMOG study. Adventist Health Study on Smog. Environ Health Perspect 1998; 106: 813-23.

27 Turner MC, Krewski D, Pope CA III, et al. Long-term ambient fine particulate matter air pollution and lung cancer in a large cohort of never-smokers. Am J Respir Crit Care Med 2011; 184: 1374-81.

28 Vineis P, Hoek G, Krzyzanowski M, et al. Air pollution and risk of lung cancer in a prospective study in Europe. Int J Cancer 2006; 119: $169-74$.

29 Hystad P, Demers PA, Johnson KC, Carpiano RM, Brauer M. Long-term residential exposure to air pollution and lung cancer risk. Epidemiology 2013; published online May 14. DOI:10.1097/ EDE.0b013e3182949ae7.

30 Schuller HM. Mechanisms of smoking-related lung and pancreatic adenocarcinoma development. Nat Rev Cancer 2002; 2: 455-63.
31 Schauer C, Niessner R, Poschl U. Polycyclic aromatic hydrocarbons in urban air particulate matter: decadal and seasonal trends, chemical degradation, and sampling artifacts. Environ Sci Technol 2003; 37: 2861-68.

32 Benbrahim-Tallaa L, Baan RA, Grosse Y, et al, for the International Agency for Research on Cancer Monograph Working Group. Carcinogenicity of diesel-engine and gasoline-engine exhausts and some nitroarenes. Lancet Oncol 2012; 13: 663-64.

33 Borm PJ, Schins RP, Albrecht C. Inhaled particles and lung cancer, part B: paradigms and risk assessment. Int J Cancer 2004; 110: 3-14.

34 Moller P, Jacobsen NR, Folkmann JK, et al. Role of oxidative damage in toxicity of particulates. Free Radic Res 2010; 44: 1-46.

35 Cesaroni G, Porta D, Badaloni C, et al. Nitrogen dioxide levels estimated from land use regression models several years apart and association with mortality in a large cohort study. Environ Health 2012; 11: 48.

36 Beelen R, Hoek G, Fischer P, van den Brandt PA, Brunekreef B. Estimated long-term outdoor air pollution concentrations in a cohort study. Atmos Environ 2007; 41: 1343-58.

37 Gulliver J, Morris C, Lee K, et al. Land use regression modeling to estimate historic (1962-1991) concentrations of black smoke and sulfur dioxide for Great Britain. Environ Sci Technol 2011; 45: 3526-32.

38 Nyberg F, Gustavsson P, Jarup L, et al. Urban air pollution and lung cancer in Stockholm. Epidemiology 2000; 11: 487-95. 